\author{
(online) $=$ ISSN $2285-3642$ \\ ISSN-L = 2285 - 3642 \\ Journal of Economic Development, Environment and People \\ Volume 3, Issue 4, 2014 \\ URL: $\underline{\text { http://jedep.spiruharet.ro }}$ \\ e-mail: office jedep@spiruharet.ro
}

\title{
Food Quality Certificates and Research on Effect of Food Quality Certificates to Determinate Ignored Level of Buying Behavioral: A Case Study in Hitit University Feas Business Department
}

\author{
Hülya ÇAĞIRAN KENDIRLi' ${ }^{1}$, Gürkan ULUSOY² \\ ${ }^{1}$ Faculty of Economics and Administrative Sciences, Hitit University, Çorum, Turkey \\ ${ }^{2}$ Institute of Social Sciences, Hitit University, Çorum, Turkey,
}

\begin{abstract}
Nowadays, food and food industry has become one of the most important sectors for manufacturers and consumers. Many countries of the world including Turkey have been developed and implemented many standards for food safety and presentation of food to ensure safe consumption. In this study, we studied on the most common of these standards through HACCP and ISO 22000 standards. The purpose of this study is, to determine students' awareness and ignores of level of food quality and food quality certification during their food shopping. This research has conducted with survey in the Hittite University, Faculty of Economics and Administrative Sciences, Business Administration by 256 students are attending to this department. Department student number is 775 in totally. We have determined some hypotheses in the context of research and we applied cluster analysis, chi-square analysis and correlation analysis to the research. According to results of a significant relationship was found between hypotheses. We considered 260 students. After calculating with 0,95 confidence interval and 0,05 tolerance we have to reach 258 students. We used the Cronbach's Alfa for testing the reliability of survey. Cronbach's Alfa is settled between 0 and 1 and for reliability of scale and it must be over 0,60 for acceptance to survey. Our survey's scale has been 0,79 and we can said that, it is a reliable scale for this survey study. According to result of research, there is no relationship between demographic specialties of students and ignored of food and quality legislation. But there is relationship between sexuality and ignored of food and quality legislation.
\end{abstract}

Keywords: Quality, Food Safety, Food Quality Certificates, HACCP, ISO 22000.

JEL classification: M31, M39

\footnotetext{
${ }^{1}$ Corresponding author. Tel.: + 9036422577 00; fax: +90 36422577 00;

E-mail address: hulyacagirankendirli@hitit.edu.tr

${ }^{2}$ Corresponding author. Tel.: +90 36830 61; fax: +90 36830 61; Email address: gurkan.ulusoy@windowslive.com
} 


\author{
(online) = ISSN $2285-3642$ \\ ISSN-L = 2285 - 3642 \\ Journal of Economic Development, Environment and People \\ Volume 3, Issue 4, 2014 \\ URL: $\underline{\text { http://jedep.spiruharet.ro }}$ \\ e-mail: office jedep@spiruharet.ro
}

\title{
Introduction
}

Quality stems etymologically from the word 'qualis' in Latin. The first information about the quality prevails in the laws of Hammurabi. Accordingly, in Turkish history, it begins to appear in the activities of 'Ahi' community and municipal laws.

The concept of standard, with its most basic sense, is a way that is repeatable and agreed on doing something. Under today's conditions, it is quite difficult to make a generic definition of quality. Developing technology, personal-cultural differences and changing consumer demands are some of the underlying reasons of that difficulty.

In Turkey and other countries of the World, food industry is leading among the industries in which quality is given much significance. Because food is an primary affordable resource for people to sustain their biological and physiological assets. Therefore, the protection of quality in the food products is a necessity in our era.

This study aims to determine consumers' awareness of the food quality certificates and the levels of noticing the food quality certificates in their food shopping.

\section{Food Quality Certificates}

In the last quarter of 1990s, food safety and quality gained importance to a great extent. Consumers paid more attention to the fact that the food, which they buy or consume, be produced in accordance with certain standards [Koç \& Bolluk, 2008]. Today's consumers demands potentially highest quality from the producers, food companies and retailers [Alpay, 2001].

Law, by-law and regulations implemented to provide food quality are defined as food legislations [Halaç, 2002]. There are many national and international standards in the areas of food safety and quality. In the study, the primary focus will be on HACCP and ISO 22000 standards which are the most known and apllied among those national and international standards.

\section{- Hazard Analysis and Critical Control Point (HACCP)}

HACCP is a systematic approach to be formed for the purpose of identifying hazards, determining and controlling pests [Aran, 1993]. HACCP, firstly, was developed by a group in the Pillsbury company which produces healthy food for the space programme named 'Apollo' in USA [Boyacıoğlu, 1993].

HACCP focuses on the control of producing process, and it is essentially a quality control system. Known widely in the food industry, HACCP aims to control or eliminate hazards to food safety [Unnevehr and Jensen, 1998]. However, HACCP applications between those who produce the same group of product and even the businesses producing the same product may differ, because critical control points are determined by in-house experts, but not universal. 


\author{
(online) $=$ ISSN $2285-3642$ \\ ISSN-L = $2285-3642$ \\ Journal of Economic Development, Environment and People \\ Volume 3, Issue 4, 2014 \\ URL: $\underline{\text { http://jedep.spiruharet.ro }}$ \\ e-mail: office jedep@spiruharet.ro
}

\title{
- ISO 22000 Food Safety Management System
}

Prepared by ISO and released in 2005, ISO 22000 standard is the first international standard to be released as 'Food Safety Management System'. ISO 22000 standard has been developed to meet some needs such as giving consumers necessary information as result of enhancing of the traceability concept, and increasing pressure of all commercial organizations and supreme board, also known as non-commercial organizations, on producing companies to ensure food safety. On the other hand, another reason is that it is compulsory to get HACCP certificate from different sources for HACCP certificates used in foreign trade, and as a consequence of this, the firms' costs have increased [Frost, 2005].

While HACCP standards are used generally by food producers, ISO 22000 standards are aimed to be used with the intention of being applied and certified by the firms in food chain (supplier, storing, distributor, and etc.) as well as food producers [Frost, 2005]. That is, ISO 22000 standard is a programme applied to all units being in relation with agricultural production and food production. With this aspect, it differs from HACCP standard having similar aim.

\subsection{A Research On Determining The Level Of Caring Food Quality Certificates in Food Shopping}

In this section of the study, the results of a field research will be present, having been applied to the students who study in the Department of Business Administration, Faculty of Economics and Administrative Sciences, Hitit University.

The main purpose of the study is to determine the awareness of consumers on the quality legislations and the levels of consumers' noticing the food quality certificates in their food shopping. In this sense the field research was carried out with 260 students, who study in the Department of Business Administration, by using face-to-face questionnaire technique.

The most appropriate model has been developed in accordance with the study's purpose. The hypotheses have been determined relating to the model developed. In the study, there are 6 hypotheses. In this sense, the hypotheses determined are as follows:

$\mathbf{H}_{1}$ : There is a significant correlation between the students' demographic characteristics and their awareness of the food quality legislations.

$\mathbf{H}_{1 \mathrm{a}}$ : There is a significant correlation between the students' gender and their awareness of the food quality legislations.

$\mathbf{H}_{1 \mathrm{~b}}$ : There is a significant correlation between the students' ages and their awareness of the food quality legislations.

$\mathbf{H}_{1 \mathrm{c}}$ : There is a significant correlation between the students' food expense groups and their awareness of the food quality legislations. 


\author{
(online) $=$ ISSN $2285-3642$ \\ ISSN-L = 2285- 3642 \\ Journal of Economic Development, Environment and People \\ Volume 3, Issue 4, 2014 \\ URL: $\underline{\text { http://jedep.spiruharet.ro }}$ \\ e-mail: office jedep@spiruharet.ro
}

$\mathbf{H}_{2}$ : There is a significant correlation between the students' demographic characteristics and and the levels of noticing the food quality certificates in their food shopping.

$\mathbf{H}_{2 \mathrm{a}}$ : There is a significant correlation between the students' gender and the level of noticing the food quality certificates in their food shopping.

$\mathbf{H}_{2 \mathrm{~b}}$ : There is a significant correlation between the students' age groups and the levels of noticing the food quality certificates in their food shopping.

$\mathbf{H}_{3}$ : There is a significant correlation between the students' levels of awareness of the food quality legislations and their level of noticing the food quality certificates in their food shopping.

\title{
1.1.1. Methodology
}

The questionnaire form has been developed by being inspired from the scale that Asoglu (2009) used in his study. A preliminary test has been done on 25 people before applying items in the questionnaire, and the questionnaire has taken its final shape after removing shortcomings.

In order to conduct research, 760 students who study in the Department of Business Administration is based on. For 760 students, the sample size is 260 , which is calculated in the confidence interval of $95 \%$ and has margin of error of 0.05 .

In this section of the study, the results of the questionnaire which is applied to the students are present. 256 questionnaires have been evaluated after removing the faulty ones out of the questionnaires applied 260 people via face-to-face questionnaire technique.

\section{- Cronbach's Alfa Analysis}

Cronbach's alpha coefficient has been used in testing scale reliability. According to Cronbach's alpha analysis, the reliability value of the variable of the level of the food quality legislations awareness is 0.69 . The reliability analysis results of the variable of the level of noticing the food quality certificates in food shopping is calculated as 0,75 . Based on Cronbach Alpha analysis results, it can be inferred that the scaled has high reliability.

Table 1:The Scale's Cronbach's Alpha Analysis

\begin{tabular}{l|l|r} 
Cronbach's Alfa Analysis & The Scale's General Reliability & 0,79
\end{tabular}

\section{- Cluster Analysis}

Cluster analysis is a multivariate statistical analysis that aims for individuals or objects to be collected in groups or clusters according to their similarities [Kurtuluş, 1998]. So it aims to classify the answers, which individuals in the research sample give to the items of questionnaire, according to their similarities. 


\author{
(online) $=$ ISSN $2285-3642$ \\ ISSN-L = 2285 - 3642 \\ Journal of Economic Development, Environment and People \\ Volume 3, Issue 4, 2014 \\ URL: http://jedep.spiruharet.ro \\ e-mail: office jedep@spiruharet.ro
}

The clusters relating to the variable of the students' levels of the food quality legislations awareness has been calculated as 51,9\% for high level of awareness; $48,1 \%$ for low level of awareness. Whereas there are 133 students in the cluster of High Level Awareness, there are 123 students in the cluster of Low Level Awareness.

Table 2: Levels Of The Food Quality Legislations Awareness

\begin{tabular}{|c|c|c|c|}
\hline \multirow{2}{*}{ Clusters } & High Level Of Awareness & Low Level Of Awareness & Anova P \\
\cline { 2 - 4 } & $51,9 \%$ & $48,1 \%$ & 0,001 \\
\hline
\end{tabular}

3 clusters have been formed relating to the variable of the level of noticing the food quality certificates in food shopping. $36,7 \%$ of the students are at a high level of noticing; $50,8 \%$ at a mid level of noticing; $12,5 \%$ at a low level of noticing.

Table 3: Levels of Noticing the Food Quality Certificates

\begin{tabular}{|c|c|c|c|c|}
\hline \multirow{2}{*}{ Clusters } & High Level of Noticing & Mid Level of Noticing & Low Level of Noticing & Anova $p$ \\
\cline { 2 - 5 } & $36,7 \%$ & $50,8 \%$ & $12,5 \%$ & 0,000 \\
\hline
\end{tabular}

Anova values relating to all clusters are less than 0,05 . It has been determined that the clusters are different from each other.

\title{
1.2. Testing Research Hypotheses
}

In this section, hypotheses and the presence-absence of correlation between variables will be analyzed by chi-square test. Research hypotheses and test results are as follows:

\subsubsection{Hypotheses 1:}

$\mathrm{H}_{1}$ : There is a significant correlation between the students' demographic characteristics and their awareness of the food quality legislations.

\section{- Hypotheses 1a sub-Hypotheses}

$\mathrm{H}_{1 \mathrm{a}}$ : There is a significant correlation between the students' gender and their awareness of the food quality legislations.

Related to the variables, Chi-square test results are included in Table 4. Chi-square value is 2,957, which is calculated at a significance level of 0,01 and degree of freedom of 1 . On the other hand, the critical value is 58.14, which is calculated again at a significance level of 0,01 and degree of freedom of 1.

Chi-square sig. value is, however, calculated as 0,085 . Since the value is more than 0,05 , it will be accepted as an absence hypothesis. In this context, $\mathrm{H}_{1 \mathrm{a}}$ sub-hypothesis will be rejected. It means that there is not any significant difference between the students' gender and their level of noticing the food quality certificates. 


\author{
(online) = ISSN $2285-3642$ \\ ISSN-L = 2285- 3642 \\ Journal of Economic Development, Environment and People \\ Volume 3, Issue 4, 2014 \\ URL: http://jedep.spiruharet.ro \\ e-mail: office jedep@spiruharet.ro
}

Table 4: Corelation Between The Students' Gender And The Awareness Level Of Food Quality Legislations

\begin{tabular}{|c|c|c|c|c|c|}
\hline & & & \multicolumn{2}{|c|}{ Awareness Level } & \multirow[b]{2}{*}{ Total } \\
\hline & & & $\begin{array}{c}\text { High Level of } \\
\text { Awareness }\end{array}$ & $\begin{array}{c}\text { Low Level Of } \\
\text { Awareness }\end{array}$ & \\
\hline \multirow{2}{*}{ GENDER } & Women & Number & 56 & 65 & 121 \\
\hline & Men & Number & 77 & 58 & 135 \\
\hline \multicolumn{2}{|c|}{ Total } & Number & 133 & 123 & \\
\hline \multicolumn{3}{|c|}{ Expected value is not less than 5 in any cell. } & D.F: 1 & \multicolumn{2}{|c|}{ Chi Square $\chi_{2}: \mathbf{2 , 9 5 7}$} \\
\hline
\end{tabular}

- Hypotheses $1 \mathrm{~b}$ and $1 \mathrm{c}$

$\mathrm{H}_{1 \mathrm{~b}}$ : There is a significant correlation between the students' ages and their awareness of the food quality legislations.

$\mathrm{H}_{1 \mathrm{c}}$ : There is a significant correlation between the students' food expense groups and their awareness of the food quality legislations.

In addition, the correlation between age groups and the ranges of monthly food expense which are the students' other demographic characteristics, have been tested. Relating to the age group, chi-square value is 0,65 . However, related to the ranges of monthly food expense, chi-square sig. value is 0,32 . Since both of values are more than 0,05 , the absence hypothesis has been accepted; but $\mathrm{H} 1 \mathrm{~b}$ and $\mathrm{H} 1 \mathrm{c}$ hypotheses have been rejected.

\title{
1.2.2. Hypotheses 2
}

$\mathrm{H}_{2}$ : There is a significant correlation between the students' demographic characteristics and the levels of noticing the food quality certificates in their food shopping.

\section{- Hypotheses 2a sub-Hypotheses}

$\mathrm{H}_{2 \mathrm{a}}$ : There is a significant correlation between the students' gender and the level of noticing the food quality certificates in their food shopping.

Chi-square analysis results related to the variables are included in Table 5. Calculated at a significance level of 0,01 and degree of freedom of 2, chi-square value is 60.759; however, expected chi-square value is 15.13. On the other side, Chi-square sig. value is 0.00 , that is, less than 0,05 . Therefore, the absence hypothesis has been rejected; the hypothesis asserting that there is difference has been accepted. In other words, it has been determined that there is a significant correlation between the students' gender and their level of noticing the food quality certificates in their food shopping, and $\mathrm{H} 2 \mathrm{a}$ sub-hypothesis has been accepted. 


\author{
(online) = ISSN $2285-3642$ \\ ISSN-L = $2285-3642$ \\ Journal of Economic Development, Environment and People \\ Volume 3, Issue 4, 2014 \\ URL: http://jedep.spiruharet.ro \\ e-mail: office jedep@spiruharet.ro
}

Table 5: Corelation Between The Students' Gender And The Level Of Noticing Food Quality Certificates.

\begin{tabular}{|c|c|c|c|c|c|c|}
\hline & & & \multicolumn{3}{|c|}{ Noticing Level } & \multirow{2}{*}{ Total } \\
\hline & & & Low Level & Normal Level & High Level & \\
\hline \multirow{2}{*}{ GENDER } & Women & Number & 11 & 92 & 18 & 121 \\
\hline & Men & Number & 21 & 38 & 76 & 135 \\
\hline \multicolumn{2}{|c|}{ Total } & Number & 32 & 130 & 94 & 256 \\
\hline \multicolumn{3}{|c|}{ Expected value is not less than 5 in any cell. } & \multicolumn{2}{|c|}{ D.F: 2} & \multicolumn{2}{|c|}{ Chi Square $\chi_{2}: 60,759$} \\
\hline
\end{tabular}

- Hypotheses $\mathbf{2 b}$ sub-Hypotheses

Belonging to the variables of the students' age group, another demographic characteristics in the questionnaire, and level of noticing the food quality certificates, chi-square sig. value is 0,00 . As it is less than $0,05, \mathrm{H} 2 \mathrm{~b}$ sub-hypothesis has been accepted.

\title{
1.2.3. Hypotheses 3
}

H3: There is a significant correlation between the students' levels of awareness of the food quality legislations and their level of noticing the food quality certificates in their food shopping.

Chi square analysis results related to the variables are included in T6. Calculated at a significance level of 0,01 , and degree of freedom of 0,01 , chi square value is 11,441 . Chi square sig. value is 0,003 , as well. Since chi square sig. value is less than 0,05 , the absence hypothesis has been rejected; but the hypothesis asserting that there is difference has been accepted. In this way, it can be said that there is a significant correlation between the students' level of the food quality awareness and their level of noticing the food quality certificates. So H3 hypothesis has been accepted.

Table 6: Corelation between the food quality legislations and the level of noticing the food quality certificates

\begin{tabular}{|c|c|c|c|c|c|c|}
\hline & & & \multicolumn{3}{|c|}{ Noticing Level } & \multirow{2}{*}{ Total } \\
\hline & & & Low Level & Normal Level & High Level & \\
\hline \multirow{2}{*}{$\begin{array}{c}\text { Awareness } \\
\text { Level }\end{array}$} & High Level & Number & 10 & 63 & 60 & 133 \\
\hline & Low Level & Number & 22 & 67 & 34 & 123 \\
\hline \multicolumn{2}{|c|}{ Total } & Number & 32 & 130 & 94 & 256 \\
\hline \multicolumn{3}{|c|}{ Expected value is not less than 5 in any cell. } & \multicolumn{2}{|c|}{ D.F: 2} & \multicolumn{2}{|c|}{ Chi Square $\chi_{2}: 11,441$} \\
\hline
\end{tabular}




\author{
(online) $=$ ISSN $2285-3642$ \\ ISSN-L = $2285-3642$ \\ Journal of Economic Development, Environment and People \\ Volume 3, Issue 4, 2014 \\ URL: $\underline{\text { http://jedep.spiruharet.ro }}$ \\ e-mail: office jedep@spiruharet.ro
}

\title{
1.2.4. Correlation Analysis
}

Correlation is referred as ' $r$ ', and its value changes between -1 and +1 . Here the direction of correlation is determined by the mark of ' $r$ ', and its degree is determined by magnitude of coefficient. Minus value shows that a variable decreases as the other increases; however, plus values shows that both variables' value increase or decrease together [Damodar, 2001].

\section{- Correlation 1}

In this section, the results of correlation analysis used in the research are given. Belonging to the variables between genders and opinions about the quality certificated products' being expensive, ' $r$ ' value has been calculated as 0,396 at a significance level of 0,01 . That is, there is a positive correlation in the mid-degree between genders and expensiveness of the quality certificated products. On the other hand, there is not a clear cause and effect relation, but it can be commented that males, rather than females, think that the quality certificated products are expensive.

\section{- Correlation 2}

The correlation between those not caring the writings on the food products and those caring quality, not price of the product is 0,646 . Accordingly, there is a high correlation in a linear direction between variables.

\section{- Correlation 3}

The correlation between the level of food and quality legislations awareness and the level of noticing the food quality certificates in food shopping has been calculated as $-0,211$ at a significance level of 0,01 . Therefore, it can be inferred that there is a low correlation in negative direction between variables.

\section{Conclusion}

To sum up the results obtained in the research:

- $51,9 \%$ of the students in the research have a high level of the food legislations awareness. However, $48,1 \%$ has a low level of the food legislations awareness.

- The expressions that form the level of noticing the food quality certificates on participants' purchasing attitudes have been categorized by a cluster analysis. According to that, $36,7 \%$ of the students have high level; $50,8 \%$ have mid-level; $12,5 \%$ have low level of noticing.

- The rate of those who know HACCP-ISO 22000 standards is $40,7 \%$.

- $59,4 \%$ of the participants know the concept of Quality Standards.

- $56,2 \%$ of the participants don't prefer the products that don't have a quality certificate.

- $62,5 \%$ of the students have stated that a quality certificate is the main reason while preferring the product.

- The awareness level of Halal Food Certificate is $80,5 \%$. On the other hand, $76,6 \%$ of the participants cares this certificate on buying meat and meat products. 


\author{
(online) $=$ ISSN $2285-3642$ \\ ISSN-L = 2285-3642 \\ Journal of Economic Development, Environment and People \\ Volume 3, Issue 4, 2014 \\ URL: $\underline{\text { http://jedep.spiruharet.ro }}$ \\ e-mail: office jedep@spiruharet.ro
}

Variables and hypotheses determined in the research have been analyzed by chi square test. According to the analysis results, significant correlations have not been found between the demographic characteristics of the students, who study in the department of Business Administration, and their awareness level of food quality legislations. H1 hypothesis has been rejected with its all sub hypotheses.

Statistically significant correlations have been determined between the students' demographic characteristics and the level of noticing the food quality certificates on buying behaviours. Accordingly the hypothesis $(\mathrm{H} 2)$ asserting that there is a significant correlation between the students' demographic characteristics and the level of noticing the food quality certificates on buying behaviours has been accepted with its all sub-hypotheses.

The relations has been tested between the students' level of food and quality legislations awareness and the level of noticing the quality certificates on their food shopping, and significant correlation has been determined. According to the analysis results, significant correlations have been found between the level of food and quality legislations awareness and the level of noticing the food quality certificates in food shopping, and $\mathrm{H} 3$ hypothesis has been accepted.

The relations between the two variables have been examined by a correlation analysis. A correlation in a negative direction and low degree has been found between the level of food and quality legislations awareness and the level of noticing the food quality certificates on buying behaviours. In brief, individuals' level of noticing the quality certificates on buying decreases while the level of the food and quality legislations awareness increases. In this situation, it is clear that the students, who study in the Department of Business Administration, Faculty of Economics and Administrative Sciences, Hitit University, are aware of the food quality legislations, but don't care the food quality certification on buying. So it can be inferred that the level of noticing the food quality certificates in food shopping decreases as the food and quality legislations awareness increases.

In the future studies on the subject, it will be suitable to conduct surveys and establish models which reveal the cause and effects of the negative correlation between the food quality legislations and the level of noticing quality certificates. 


\author{
(online) $=$ ISSN $2285-3642$ \\ ISSN-L = 2285 - 3642 \\ Journal of Economic Development, Environment and People \\ Volume 3, Issue 4, 2014 \\ URL: http://jedep.spiruharet.ro \\ e-mail: office jedep@spiruharet.ro
}

\title{
References
}

[1] Alpay, Ş. (2001). Avrupa Birliği Kalite Ve Sağlık Standartlarının Türk Gıda Sanayii Sektörü Rekabet Gücü Üzerine Etkisi, Ankara, Tarımsal Ekonomi Araştırma Enstitüsü Yayın No: 59.

[2] Aran, N. (1993), Gıda Endüstriside Kritik Kontrol Noktalarında Tehlike Analizleri Sistemi, Gıda Sanayinde Mikrobiyoloji Ve Uygulamaları, Kocaeli, Tübitak-Marmara Araştırma Merkezi.

[3] Boyacıoğlu, D. (1993), Gıda Kalite Kontrolünde Kritik Kontrol Noktalarının Tehlike Analizi Sistemi Ve Uygulamaları, Gıda Dergisi, p. 297

[4] Damodar N. G. (2001), Basic Econometric, Çeviren: Ümit Ş. \& Gülay G. Ş., İstanbul, Literatür Yayıncılık.

[5] Frost, R. (2005). Iso 22000 Standard For Safe Food Supply Chains. Iso Management Systems, Iso Insider, JulyAugust 2005, p.321.

[6] Halaç, E. (2002)Türkiye Gıda Sanayinde Kalite Ve Güvenlik Standartları: Kavramlar, Mevzuat Ve Uygulamalar, Akdeniz Üniversitesi, Sosyal Bilimler Enstitüsü, İktisat Anabilim Dalı, Yayınlanmış Yüksek Lisans Tezi, Antalya.

[7] Koç, A.; Boluk, G. (2008), Gıda Güvenliği Ve Kalite, Akdeniz libf (16) p. 83- 115

[8] Kurtuluş, K. (1998), Pazarlama Araştırmaları, İstanbul, Avcıol Basım Yayın, 6. baskı.

[9] Unnevehr, L.J.; Jensen, H.H. (1998), The Economics Implications Of Using Haccp As A Food Safety Regulatory Standard, Food Policy, p. 625-635. 